\title{
МОДЕЛЮВАННЯ ЗМІНИ МІКРОСТРУКТУРИ \\ ОПРОМІНЮВАНИХ СИСТЕМ МЕТОДОМ ФАЗОВОГО ПОЛЯ КРИСТАЛА
}

\author{
Д.О. ХАРЧЕНКО, В.О. ХАРЧЕНКО, С.В. КОХАН, І.О. ЛИСЕНКО
}

УДК 539.24

(C) 2012
Інститут прикладної фізики НАН України

(Вул. Петропавлівсъка, 58, Суми 40030; e-mail: dikh@ ipfcentr. sumy. ua)
Проведено дослідження зміни мікроструктури систем, підданих дії балістичного потоку, що описує формування структурного безладу при опроміненні із використанням методу фазового поля кристала. Виявлено, що внаслідок конкуренції регулярної та стохастичної компонент балістичного потоку в системі можливе формування структур з розмитими атомними густинами. Проведено дослідження динаміки дефектів при рекристалізації такої системи та встановлено характер зміни кількості дефектів залежно від статистичних властивостей балістичного потоку. Встановлено, що при рекристалізації просторові структури, сформовані під час дії такого потоку, є стаціонарними і стійкими до термічних флуктуацій малої інтенсивності.

\section{1. Вступ}

Дослідження мікроструктури кристалічних матеріалів, умов, за яких вона зазнає змін, та характеру самих перетворень у матеріалах є актуальним завданням на сьогодні не лише з точки зору теоретичної фізики, а й фізики твердого тіла та матеріалознавства загалом [1]. Останніми роками вирішення цієї проблеми стає вельми важливим, оскільки пов'язано із встановленням стійкості конструкційних матеріалів, що використовуються у різних областях людської діяльності, зокрема радіаційної техніки [2]. Еволюція таких систем задається термодинамічними силами, механічними навантаженнями або радіаційним опроміненням. Механічна нестійкість кристалічних систем приводить до формування дефектів (точкових, лінійних, пласких та об'ємних), які здатні сильно впливати на характер поведінки таких систем за різних умов ïх використання. Тому розуміння і вивчення процесів формування структур дефектів та їхньої динаміки становить незникаючий науковий інтерес впродовж останніх декількох десятиріч.

За останні роки з'ясувалося, що адекватний опис мікроструктурних перетворень може бути досягнутий самоузгодженим розгляданням поведінки таких систем на різних ієрархічних рівнях: від просторовочасових масштабів квантово-механічного рівня до макроскопічних [3]. Окреме використання методів теоретичної фізики на певному ієрархічному рівні такої мультимасштабної схеми не дозволяє подати повну картину самоорганізації кристалічної або ж дефектної структури. Так, наприклад, методи $a b$ initio дозволяють подати картину поведінки системи на довжинах порядку $10^{-9}$ м та часових інтервалах $\sim 10^{-14}$ с. Динаміка атомів та точкових дефектів, досліджувана методами молекулярної динаміки, обмежується інтервалами $\sim 10^{-9}-10^{-8} \mathrm{M}, \sim 10^{-13}-10^{-8}$ с. Важливо зазначити, що кількість атомів, задіяних у таких процесах числового моделювання, є скінченою величиною: ефективність ab initio підходів обмежується розглядом $10^{6}$ атомів; молекулярної динаміки $10^{9}$ атомів. Використання аналітичних підходів для дослідження мікроструктури у поєднанні із числовими методами (кінетичне моделювання Монте-Карло) доволі успішно використовується на дифузійних масштабах, де у межах використання певних граничних умов досліджувана система може розглядатися у термодинамічній границі. Серед найпоширеніших підходів виділяють метод фазового поля, що грунтується на теорії Гінзбурга-Ландау [4].

Однак серед наведених підходів можна виділити так звані гібридні підходи та методи, які охоплюють декілька ієрархічних рівнів. Серед них найпопулярнішим і найвживанішим для дослідження мікростру- 
ктури матеріалів є метод фазового поля кристала, який у межах розгляду континуального поля атомної густини дозволяє описати кристалічні системи різної симетрії. Основу методу було запозичено із гідродинаміки при описі формування комірок Релєя-Бенара [5]. Фізичний зміст його застосування для кристалічних систем закладено у теорії затвердівання [6], яку було розвинуто відповідно до теорії ГінзбургаЛандау у працях Елдера, Гранта та ін. [7]. У межах цього підходу кристалічна фаза характеризується періодично розподіленим полем атомної густини $\rho(\mathbf{r})$, що відповідає мінімуму функціоналу вільної енергії $\mathcal{F}[\rho(\mathbf{r})]$. Його перевагою перед стандартною теорією фазового поля $€$ можливість моделювання довгочасної еволюції матеріалів на мікроскопічному просторовому масштабі у порівнянні з методами молекулярної динаміки - у вилученні швидких ступенів вільності, що дозволяє дослідити динаміку системи на мезоскопічних часах. Цей метод виступає у ролі інструменту огрублення у часі молекулярної динаміки $\tau$ (усереднення за фононами) [8]. Тобто замість положень атомів розглядаються відповідні атомні густини як ймовірності заповнення фазового об'єму кожним $i$-м атомом, тобто $\rho(\mathbf{r}, \tau)=\tau^{-1} \int_{0}^{\tau} \mathrm{d} t \rho_{m}(t)$, де $\rho_{m}(\mathbf{r}, t)=\sum_{i}^{N} \delta\left(\mathbf{r}-\mathbf{r}_{i}(t)\right)$. Крім того, це дозволяе моделювати пружні та пластичні деформації кристалів, переходи рідина-тверде тіло [9], дифузію дефектів [10], мікроструктурні перетворення [11], фазове розшарування, епітаксійне зростання, динаміку дислокації [12], структурні переходи [13, 14].

Очевидно, що застосування такого методу для дослідження мікроструктурних змін опромінюваних матеріалів та поведінки дефектів при рекристалізації відповідних систем виглядає доволі ефективним. Оскільки є добре поєднання такого підходу із результатами молекулярної динаміки, то можливим стає виявлення перерозподілу дефектів при рекристалізації, вивчення руху дислокацій, границь зерен та поведінки мікротріщин. При цьому необхідно ввести у розгляд відповідні сили та потоки, які спричиняють формування структурного безладу, викликаного дією опромінення. Використавши підходи, розвинуті у роботах [15-17], дія опромінення з формуванням структурного безладу адекватно описується введенням у розгляд балістичного (атермічного) потоку атомного перемішування. Цей потік приводить до додаткової (балістичної) дифузії атомів, яка буде мати стохастичний характер [18]. Добре відомо, що у нелінійних розподілених системах нерівноважні флуктуації здатні спричиняти якісну перебудову системи, що є неможливим у рівноважних умовах [19-21], наприклад, фазові переходи [22], фазове розшарування [23], структуроутворення в об'ємі [24] та на поверхні $[25,26]$. Тому постає важливе питання про вплив статистичних властивостей балістичного потоку на мікроструктурні перетворення у кристалічних системах. При цьому можливим стає опис формування дефектів при опроміненні та їх відпалі [27-29].

Таким чином, метою даної роботи є вивчення характеру мікроструктурних перетворень в опромінюваних кристалічних системах, при введенні у розгляд балістичного потоку зі стохастичними властивостями (шумом). Для досягнення поставленої мети застосовано формалізм фазового поля кристала. Розглянуто загальний підхід на випадок двовимірних систем, який у подальшому може бути розвинений на тривимірні системи. Показано, що внаслідок стохастичного впливу у системі можуть реалізуватися метастабільні, але стійкі структури іншої симетрії, ніж вихідний кристал. Проведено дослідження процесів перерозподілу атомної густини під час дії атермічного потоку та з'ясовано динаміку дефектів у процесах рекристалізації опроміненої системи.

Структура роботи є такою. У наступному розділі запропоновано основну модель кристалічної системи та введено балістичний потік. У розділі 3 вивчено характер зміни мікроструктури при опроміненні та рекристалізації методами числового моделювання. Обговорення отриманих результатів проведено у розділі 4. Останній розділ містить висновки.

\section{2. Модель}

У межах стандартного формалізму фазового поля кристала періодична система (кристал) та можливі структурні переходи у ній описано зміною властивостей поля атомної густини $\rho(\mathbf{r}, t)$. Будемо розглядати однокомпонентні системи 3 властивостями $\int \mathrm{d} \mathbf{r} \rho(\mathbf{r}, t)=\rho_{0}, \rho_{0}=$ const, для якої зміну вільної енергії $\Delta \mathcal{F}=\mathcal{F}[\rho]-\mathcal{F}\left[\rho_{0}\right]$ подано виразом [12]:

$$
\begin{aligned}
& \frac{\Delta \mathcal{F}}{T}=\int \mathrm{d} \mathbf{r}\left\{\rho(\mathbf{r}) \ln \left[\rho(\mathbf{r}) / \rho_{0}\right]-\Delta \rho(\mathbf{r})\right\}- \\
& -\frac{1}{2} \int \mathrm{d} \mathbf{r}_{1} \int \mathrm{d} \mathbf{r}_{2} \Delta \rho\left(\mathbf{r}_{1}\right) c^{(2)}\left(\mathbf{r}_{1}, \mathbf{r}_{2}, \rho_{0}\right) \Delta \rho\left(\mathbf{r}_{2}\right),
\end{aligned}
$$

де $\Delta \rho(\mathbf{r})=\rho(\mathbf{r})-\rho_{0} ; c^{(2)}\left(\mathbf{r}_{1}, \mathbf{r}_{2}, \rho_{0}\right)$ - двоточкова кореляційна функція; перший доданок описує вільну систему, другий характеризує взаємодію. Цей вираз є справедливим лише при слабкій варіації $\Delta \rho(\mathbf{r})$, однак похибка такого наближення становить лише декілька 
відсотків при описі процесів тверднення, тому, за певних слабких умов, його можна вважати задовільним [12]. Загальний формалізм теорії фазового поля кристала полягає у таких двох основних припущеннях. У припущенні про слабкість варіації $\Delta \rho(\mathbf{r})$ при зміні $c^{(2)}$ розвинення за квадратом хвильового числа дає $\rho_{0} c^{(2)}(q) \simeq C_{0}+C_{2} q^{2}+C_{4} q^{4}$. Сталі $C_{0}<0, C_{2}>0$, $C_{4}<0$ задають властивості конкретної кристалічної системи (матеріалу), а саме, ізотермічну стисливість рідинної фази: $\sim 1-\rho_{0} C_{0}$ (знерозмірений об'ємний модуль рідинного стану), об'ємний модуль у кристалічній фазі $\sim \rho_{0} C_{2}^{2} / 4\left|C_{4}\right|$ та сталу гратки $a_{0} \sim \sqrt{\left|C_{4}\right| / C_{2}} 1$. Розвинення у ряд невзаємодіючої частини в околі $\rho_{0}$ дозволяє подати функціонал вільної енергії для знерозміреного поля атомної густини $x(\mathbf{r}) \propto \Delta \rho(\mathbf{r}) / \rho_{0}$ у вигляді [14]:

$\mathcal{F}=\int \mathrm{d} \mathbf{r}\left(f(x)+\frac{1}{2} x \mathcal{L}\left(\nabla^{2}\right) x\right)$,

де густина вільної енергії $f(x)$ та оператор просторової взаємодії $\mathcal{L}\left(\nabla^{2}\right)$ подають виразами

$f(x)=\frac{\alpha\left(T-T_{m}\right)}{2} x^{2}+\frac{u}{4} x^{4}, \quad \mathcal{L}\left(\nabla^{2}\right)=\beta\left(q_{0}^{2}+\nabla^{2}\right)^{2}$,

визначеними через матеріальні сталі $\alpha, u, \beta, T_{m}-$ температура топлення, $q_{0}$ - хвильове число, що задає параметр гратки. Зв'язок між параметрами теорії та мікроскопічними параметрами конкретної кристалічної системи встановлюється відповідно до процедури, описаної, наприклад, у роботі [14].

Оскільки поле атомної густини є збережним, то його ланжевенівську динаміку задано рівнянням

$\partial_{t} x=M \nabla^{2} \frac{\delta \mathcal{F}}{\delta x}+\xi$

де $M=$ const - атомна рухливість, $\xi$ - білий шум із стандартними властивостями: $\langle\xi(\mathbf{r}, t)\rangle=0$, $\left\langle\xi(\mathbf{r}, t) \xi\left(\mathbf{r}^{\prime}, t^{\prime}\right)\right\rangle=2 M T \nabla^{2} \delta\left(\mathbf{r}-\mathbf{r}^{\prime}\right) \delta\left(t-t^{\prime}\right)$.

$\mathrm{У}$ подальшому доцільно провести перенормування величин:

$\mathbf{r}^{\prime}=\mathbf{r} q_{0}, x^{\prime}=x \sqrt{u / T_{m} \beta q_{0}^{4}}, \varepsilon^{\prime}=\alpha \Delta T / T_{m} \beta q_{0}^{4}$,

$t^{\prime}=M \beta q_{0}^{6} t, \mathcal{F}_{0}=\beta^{2} q_{0}^{8-d} T_{m} / u, \mathcal{F}^{\prime}=\mathcal{F} / \mathcal{F}_{0}$,

$1 \mathrm{y}$ двовимірному випадку параметр гратки $a_{0}=2 \pi / q_{0}$ задається хвильовим числом $q_{0}=\sqrt{3 C_{2} / 8\left|C_{4}\right|}$, для тривимірного випадку $q_{0}^{3 d}=\sqrt{C_{2} /\left|C_{4}\right|}[12]$ увести до розгляду керуючий параметр $\varepsilon=\theta-1$, $\theta=T / T_{m}$ та перенормувати флуктуаційне джерело

$\langle\xi(\mathbf{r}, t)\rangle=0$,

$\left\langle\xi(\mathbf{r}, t) \xi\left(\mathbf{r}^{\prime}, t^{\prime}\right)\right\rangle=\frac{u \theta q_{0}^{d-4}}{\beta^{2}} \nabla^{2} \delta\left(\mathbf{r}-\mathbf{r}^{\prime}\right) \delta\left(t-t^{\prime}\right)$

Далі для зручності штрихи опускаємо. Слід зазначити, що у системі за певних умов (вибраного значення густини $x_{0}$ ) можливою стає реалізація структур гексагонального типу (періодичного розподілу атомної густини) i, так званих, страйпів (лінійних структур). У будь-якому випадку утворення просторових структур стає можливим лише за умови $x_{0} \leq \sqrt{1-\theta}$, тобто якщо густина вільної енергї є бімодальною. У протилежному випадку система є однорідною незалежно від значення вибраної густини. У випадку двовимірної системи при $\mathcal{L}=\left(1+\nabla^{2}\right)^{2}$ загальний розв'язок рівняння станів може бути подано у вигляді

$x(\mathbf{r}, t)=x_{0}+s(t)\left(e^{i \mathbf{k}_{1} \mathbf{r}}+\right.$ c.c. $)+h(t)\left(e^{i \mathbf{k}_{2} \mathbf{r}}+e^{i \mathbf{k}_{3} \mathbf{r}}+\right.$ c.c. $)$,

де с.с. означає комплексне спряження; $s(t), h(t)$ - амплітуди; хвильові вектори є такими:

$\mathbf{k}_{1}=\left(-\frac{\sqrt{3}}{2},-\frac{1}{2}\right), \quad \mathbf{k}_{2}=(0,1), \mathbf{k}_{3}=\left(\frac{\sqrt{3}}{2},-\frac{1}{2}\right)$

Тому у випадку $s=h$ маємо гексагональну фазу - періодичну структуру розподілу атомної густини (кристал). Це означає, що атом знаходиться в околі свого рівноважного положення, атоми блукають у сферично симетричній області в околі своїх положень 3 періодом гратки $a=2 \pi / q_{0}$, а частота перебування у кожній точці в околі рівноважного положення $\mathbf{r}_{i}$ визначається величиною $x_{0}\left(\mathbf{r}_{i}\right)$. При $h=0$ реалізуються лінійні структури. Це означає, що, незважаючи на періодичну структуру розподілу атомної густини за атомними площинами, у стаціонарному випадку вона розмивається паралельно атомним площинам, тобто атоми можуть рухатися вздовж атомних площин. В області однорідних станів $(s=h=0)$ атомна густина розмита по всій системі, яка фактично знаходиться у стані рідини. Можливі області співіснування кристалічної (гексагональної) фази і однорідних станів, також реалізується область співіснування гексагональної і лінійної структур. Цю проблему вивчали раніше (див., наприклад, [30]), де встановлено критичні значення для реалізації наведених структур у одно- 
та двовимірному випадках. Методами числового моделювання досліджено особливості утворення періодичних структур розподілу атомної густини у тривимірних системах, де встановлено можливість формування ГЦК, ОЦК та ГПУ структур, які у двовимірному випадку відповідають області існування гексагональної фази [31, 32]. Як було показано раніше [7], пружні властивості гексагональної фази у двовимірному випадку описується пружними сталими: $C_{12}=$ $C_{44}=C_{11} / 3$, де $C_{12}=\left[\left(3 x_{0}+\sqrt{-15 \varepsilon-36 x_{0}^{2}}\right) q_{0}^{2}\right]^{2} / 75$, $C_{11}=C_{12}+2 C_{44}$; при цьому коефіцієнт Пуассона $\nu=1 / 3$, модуль зсуву $\mu=C_{44}$, модуль Юнга $Y_{2}=8 C_{12} / 3$.

Вплив опромінення враховуємо, вводячи потік атермічного перемішування атомної системи [18]:

$\mathbf{J}_{e}=-\left(D_{e}+\zeta(\mathbf{r}, t)\right) \nabla x, \quad D_{e}=\phi\langle R\rangle^{2} \sigma_{r}$,

який має регулярну та стохастичну складові. Регулярна частина характеризує радіаційно стимульовану дифузію, яку задають коефіцієнтом балістичної дифузії $D_{e}$, визначеним через потік опромінення $\phi$, середню довжину стрибка вибитого атома $\langle R\rangle$ та перетин розсіяння $\sigma_{r}$. Величини $\sigma_{r}$ i $\langle R\rangle$ визначаються енергією бомбардуючих частинок. Стохастична компонента, що має гаусові властивості, описує формування структурного безладу. Оскільки розглядається стохастичне перемішування у структурованому середовищі (кристалі), то очевидно, що випадкова складова має бути скорельованою у просторі. Ї̈̈ властивості виберемо такими:

$\langle\zeta(\mathbf{r}, t)\rangle=0$

$\left\langle\zeta(\mathbf{r}, t) \zeta\left(\mathbf{r}^{\prime}, t\right)\right\rangle=\frac{2 D_{e} \sigma^{2}}{\left(\sqrt{2 \pi} r_{c}\right)^{d}} e^{-\left(\mathbf{r}-\mathbf{r}^{\prime}\right)^{2} / 2 r_{c}^{2}} \delta\left(t-t^{\prime}\right)$.

Наявність $D_{e}$ у кореляторі свідчить про те, що шум $\zeta$ виникає лише за наявності потоку опромінення. Інтенсивність шуму $\sigma^{2}=\left\langle(\delta R)^{2}\right\rangle /\langle R\rangle^{2}$ пов'язана із дисперсією довжини стрибків вибитих атомів, $r_{c}-$ paдіус просторових кореляцій. Така конструкція атермічного потоку перемішування дозволяє розглядати випадки, що не обмежуються звичайною дифузією, описаною лапласіаном у рівнянні еволюції, а приводить до узагальненого стохастичного характеру руху iз заданою дисперсією стрибків $\left\langle(\delta R)^{2}\right\rangle$. Тому надалі доцільно розглядати $D_{e}$ та $\sigma^{2}$ як два незалежних параметри теорії [18]. Отже, повне рівняння еволюції поля атомної густини набуває вигляду

$\partial_{t} x=\nabla^{2} \frac{\delta \mathcal{F}}{\delta x}+\xi(\mathbf{r}, t)+\nabla \cdot\left(D_{e}+\zeta(\mathbf{r}, t)\right) \nabla x$.
Особливості формування періодичного розподілу атомної густини у системі із атермічним потоком перемішування, яка описується рівнянням (8) за різних початкових значень атомної густини проведено у роботі [33]. Поведінку нерівноважної системи, коли час поширення збурень атермічним потоком та звичайним дифузійним різняться, розглянуто у роботі [34]. Було встановлено, що, незалежно від початкового значення $x(\mathbf{r}, t=0)$, дія скорельованого стохастичного джерела $\zeta(\mathbf{r}, t)$ здатна переводити систему до стану з утворенням лінійних структур. Інакше кажучи, формування структурного безладу у скорельованому середовищі внаслідок опромінення приводить до зміни мікроструктури кристала з формуванням упорядкованих фаз, розділених неупорядкованими, розмиття густини вздовж атомних площин та гомогенізації розподілу густини - розтоплення кристала. Однак природу переходів від гексагональних структур до лінійних, викликаних дією зовнішнього стохастичного джерела, не було вивчено.

Незважаючи на те, що процеси утворення упорядкованих конфігурацій вивчалися раніше, дослідження зміни мікроструктури із вивченням характеру формування дефектів за наявності атермічного перемішування не проводилося. Тому у даній роботі за мету ставлять з'ясування поведінки утворення дефектів у кристалічній системі під час дії атермічного потоку перемішування. Основні властивості формування структур дефектів досліджуватимуться у межах використання геометричного підходу із визначенням порушення ідеальності гексагональної структури та формування дислокацій.

\section{3. Особливості зміни мікроструктури}

\section{1. Лінеаризована модель: структурний фактор}

Розглянемо спочатку лінеаризовану модель в околі досліджуваного значення густини $x_{0}$. Оскільки величина $x$ є збережною, то аналіз на стійкість проводиться для сферично-усередненого структурного фактора $S(k, t)$ як фур'є-перетворення двоточкової кореляційної функції $\left\langle\delta x(\mathbf{r}, t) \delta x\left(\mathbf{r}^{\prime}, t\right)\right\rangle$, де $\delta x(\mathbf{r}, t)=$ $x(\mathbf{r}, t)-x_{0}$. Відповідно до теореми Новікова [35] динамічне рівняння для $S(k, t)$ набуває вигляду

$\frac{\mathrm{d} S(k, t)}{\mathrm{d} t}=-2 k^{2} \omega(k) S(k, t)+2 \theta k^{2}+$

$+\frac{2 k^{2} D_{e} \sigma^{2}}{(2 \pi)^{d}} \int \mathrm{d} \mathbf{q} C(|\mathbf{k}-\mathbf{q}|) S(\mathbf{q}, t)$ 
де $C(|\mathbf{k}-\mathbf{q}|)$ - фур'є-перетворення кореляційної функції зовнішнього шуму. При цьому закон дисперсї $\mathrm{\epsilon}$ таким:

$\omega(k)=\tilde{\varepsilon}+D_{e}+\left(1-k^{2}\right)^{2}-$

$-D_{e} \sigma^{2} C(0) k^{2}+D_{e} \sigma^{2}\left[\nabla^{2} C(|r|)\right]_{r=0}$,

де $\tilde{\varepsilon} \equiv \varepsilon+3 x_{0}^{2},\left[\nabla^{2} C(|r|)\right]_{r=0}<0$ внаслідок того, що у точці $r=0$ шумовий корелятор має максимум. 3 отриманого закону випливає, що зовнішній потік приводить до перенормування керуючого параметра так, що поведінка системи визначатиметься його ефективним значенням

$\varepsilon_{\text {ef }}=\tilde{\varepsilon}+D_{e}+D_{e} \sigma^{2}\left[\nabla^{2} C(|r|)\right]_{r=0}$.

Очевидно, що при $\varepsilon_{\mathrm{ef}}<0$ збурення гармонік в околі $k_{0}=1$ зростають, результатом чого є формування періодичних структур. Із наведеного випливає, що регулярна компонента $D_{e}$ атермічного потоку приводить до зростання ефективної температури. Якщо частинки у потоці опромінення мають розкид за енергіями (імпульсами) $\left(\sigma^{2} \neq 0\right)$, то, враховуючи, що $\left[\nabla^{2} C(|r|)\right]_{r=0}<0$, стохастична складова потоку $\mathbf{J}_{e}$ приводить до порушення стійкості, зменшуючи значення ефективного керуючого параметра. Таким чином, регулярна і стохастична складові потоку опромінення $\mathbf{J}_{e}$ мають протилежний вплив на динаміку системи, що узгоджується з результатами теорії середнього поля для детерміністичних систем [15] та аналізом поведінки систем зі стохастичним потоком опромінення [18]. Детальний аналіз впливу стохастичної компоненти атермічного потоку перемішування на стійкість однорідних станів детально проведено у роботах [33, 34, 36-38]. Було з'ясовано, що на відміну від інтуїтивних міркувань про вплив шуму дія просторово-скорельованого стохастичного джерела у системах зі збережною динамікою приводить до просторового упорядкування [19, 39-41].

Із закону дисперсії знаходимо критичні значення хвильових чисел $k \in\left(k_{c}^{(-)}, k_{c}^{(+)}\right)$, які обмежують область існування нестійких мод:

$$
\begin{aligned}
& \left(k_{c}^{( \pm)}\right)^{2}=1+\frac{1}{2}\left(D_{e} \sigma^{2} C(0) \pm\right. \\
& \pm\left\{D_{e} \sigma^{2} C(0)\left(4+D_{e} \sigma^{2} C(0)\right)-\right. \\
& \left.\left.-4\left(\tilde{\varepsilon}+D_{e}-D_{e} \sigma^{2}\left|\nabla^{2} C(|r|)\right|_{r=0}\right)\right\}^{1 / 2}\right) .
\end{aligned}
$$

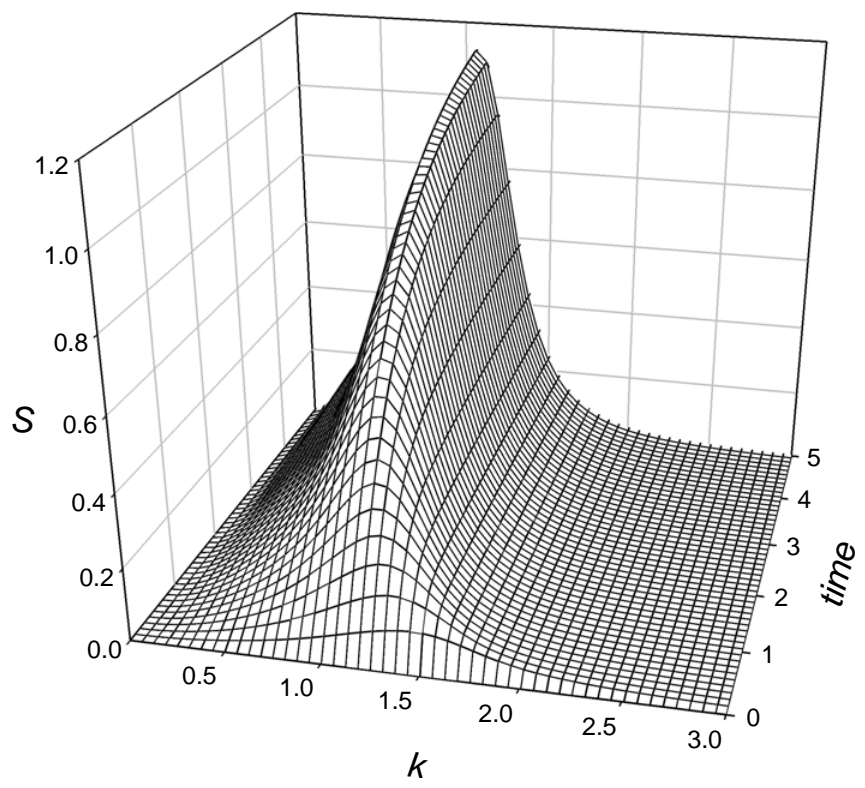

Рис. 1. Динаміка сферично усередненого структурного фактора в околі $x_{0}=0,3$ при $D_{e}=0,8, \theta=0,7, \sigma^{2}=1,0, r_{c}=1$

За таких значень хвильових чисел фактор підсилення $R(k)=-k^{2} \omega(k)$ набуває нульових значень. Максимум функції $R(k)$ досягається при $k=k_{m}$, де

$\left(k_{m}\right)^{2}=\frac{2}{3}+\frac{1}{3}\left(D_{e} \sigma^{2} C(0) \pm\right.$

$\pm\left\{1+D_{e} \sigma^{2} C(0)\left(4+D_{e} \sigma^{2} C(0)\right)-\right.$

$\left.\left.-3\left(\tilde{\varepsilon}+D_{e}-D_{e} \sigma^{2}\left|\nabla^{2} C(|r|)\right|_{r=0}\right)\right\}^{1 / 2}\right)$.

При високих температурах і фіксованому значенні $D_{e}$ збільшується критичне значення $\sigma^{2}$, тоді як збільшення $D_{e}$ спонукає до упорядкування при меншій інтенсивності шуму $\sigma^{2}$.

Динаміку структурного фактора, як розв'язку рівняння (9) зображено на рис. 1. 3 якого видно, що з часом положення основного піка $S(k, t)$ зсувається до хвильового числа $k=k_{0}$, що відповідає періоду утворюваних структур. При цьому його висота зростає, що свідчить про проходження упорядкування у системі.

\section{2. Моделювання мікроструктурних перетворень}

Проаналізуємо характер зміни поведінки системи, коли вирощений кристал піддають опроміненню протягом певного часу з утворенням дефектів кристалічної 

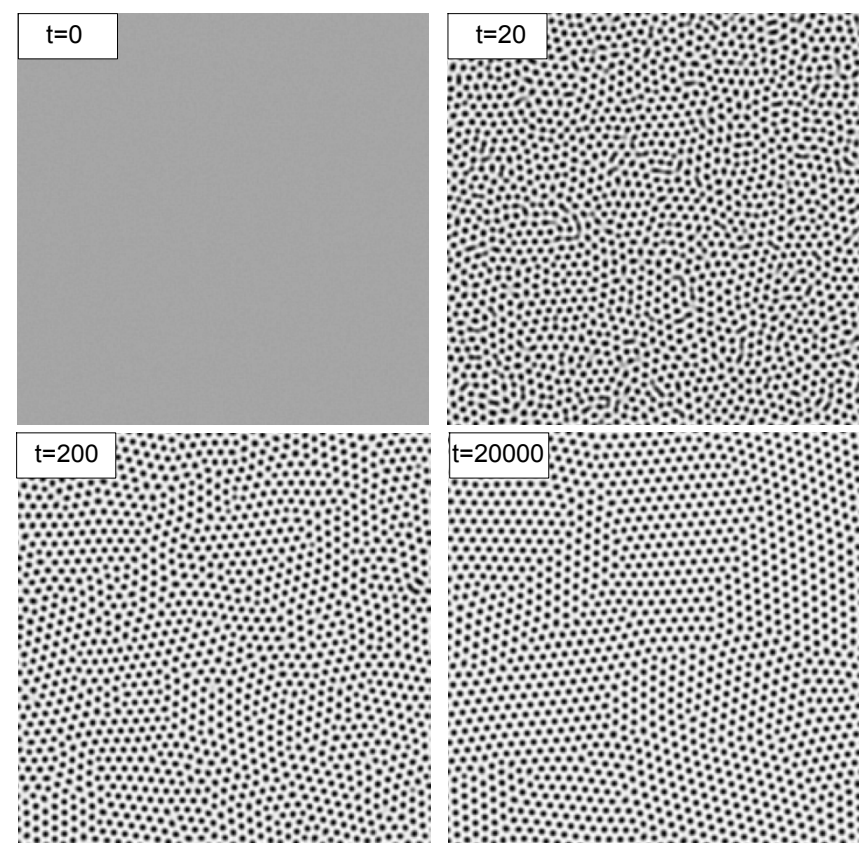

Рис. 2. Етапи еволюції системи при $\theta=0,7$ при вирощуванні кристала

будови, а потім в ньому відбувається відпал цих дефектів. Така процедура проводилася чисельно. Для цього нами чисельно розв'язано рівняння Ланжевена (8) на двовимірній квадратній гратці розміром $L=N \ell$, де $N=256$ - кількість вузлів, $\ell=1$, граничні умови періодичні. На стадії вирощування кристала із рідинної фази початкові умови були такими: $\langle x(\mathbf{r}, t)\rangle=0,3$, $\left\langle(\delta x)^{2}\right\rangle=0,1$. Всі результати отримано при $\theta=0,7$, $r_{c}=0,65$.

Типова картина формування кристала із рідинної фази наведено на рис. 2. Із сформованих зародків кристалічної фази по всьому зразку виростають кристаліти до зіткнення між собою. Після того як вся система заповнюється гексагональною фазою, подальша еволюція продовжується рухом границь зерен. Після формування основної структури відбувається перерозподіл “атомів" (темні кружки) так, щоб утворювана конфігурація мала якнайменшу кількість дефектів, зменшуючи енергію всього об'єкта. Характерний знерозмірений час росту кристала становив $t=$ $2 \cdot 10^{4}$, що відповідало переходу до стаціонарного режиму та перебудові атомної конфігурації зі зменшенням кількості дефектів. У подальшому цей об'єкт буде піддано опроміненню з різними $D_{e}$ та $\sigma^{2}$. Основним завданням на цьому етапі буде дослідження динаміки кількості дефектів та особливостей перебудо- ви мікроструктури при опроміненні та рекристалізаціï.

Розглянемо спочатку основні сценарії зміни мікроструктури при опроміненні вихідного кристалічного зразка. Перша колонка на рис. 3, $а$ відображає вплив регулярної компоненти атермічного потоку перемішування $\left(\sigma^{2}=0\right)$. Видно, що з часом відбувається розтоплення на дефектах, які були сегреговані на границях зерен. При цьому залишаються найбільш стійкі структури, які відповідають ідеальній конфігурації гексагональної симетрії. На фінальній стадії, при малих значеннях $D_{e}$, залишаються кристаліти ідеальної структури, занурені в неупорядковану фазу, де атомна густина розмита за всіма положеннями атомів. Це означає, що внаслідок проходження неперервних каскадів (у нашій моделі) відбувається розтоплення областей, що мають енергію більшу, ніж ідеальні кристалічні області. Знерозмірений час опромінення становив $t=10^{3}$, що відповідало реалізації стаціонарної структури. Фактично ця картина характеризує проходження додаткових (радіаційностимульованих) процесів дифузіі, коли мобільними стають дефекти, структури із великою кількістю дефектів є нестійкими до таких збурень. Із визначення ефективного керуючого параметра (11) випливає, що вплив регулярної компоненти атермічного потоку перемішування збільшує ефективну температуру, переводячи систему до області рідинної фази або співіснування кристалічної та рідинної фази. При великих $D_{e}$ ефективна температура стає настільки великою, що вихідна кристалічна система потрапляє в область рідинної (розтопленої) фази.

Піддамо тепер нашу систему рекристалізації (див. колонку 2 на рис. $3, a)$. Якщо у ролі початкової конфігурації вибрати останню, що відповідала кінцевому часу опромінення, та покласти $D_{e}=0$, відповідні процеси кристалізації будуть проходити 3 існуючих кристалітів. Тут хвиля атомних збурень буде поширюватись рівномірно за всіма можливими напрямками у такий спосіб, що підстроювані атоми до основного кристаліта будуть сприяти формуванню ідеальної структури зерен. Залежно від величини $D_{e}$ кількість вихідних кристалітів при рекристалізації може змінюватися, тому загальна кількість дефектів, що залишаться на фінальній стадії цього процесу, може також зазнавати змін.

Більш цікавим є стохастичний випадок, коли опромінення відбувається за наявності флуктуацій атермічного потоку $\left(\sigma^{2} \neq 0\right)$. Тут, залежно від співвідношення між регулярною та стохастичною складовими цього потоку, можливі два типи структур, що спо- 


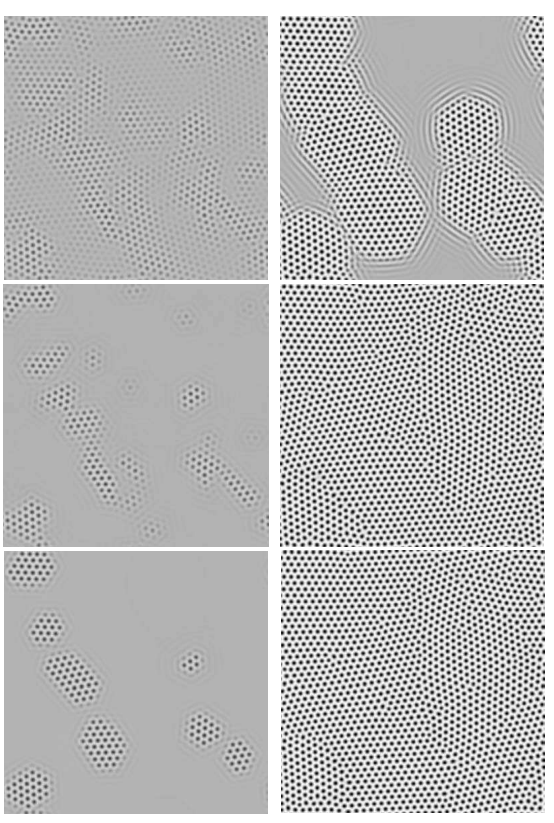

$a$

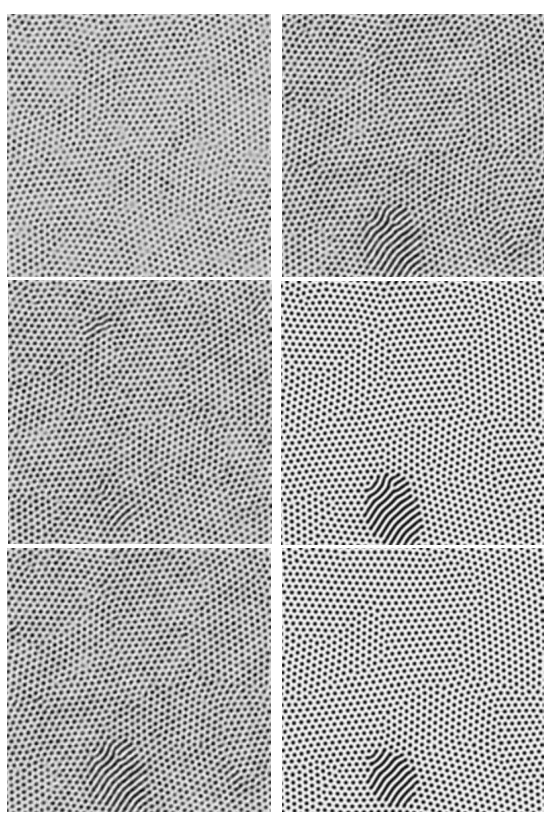

б
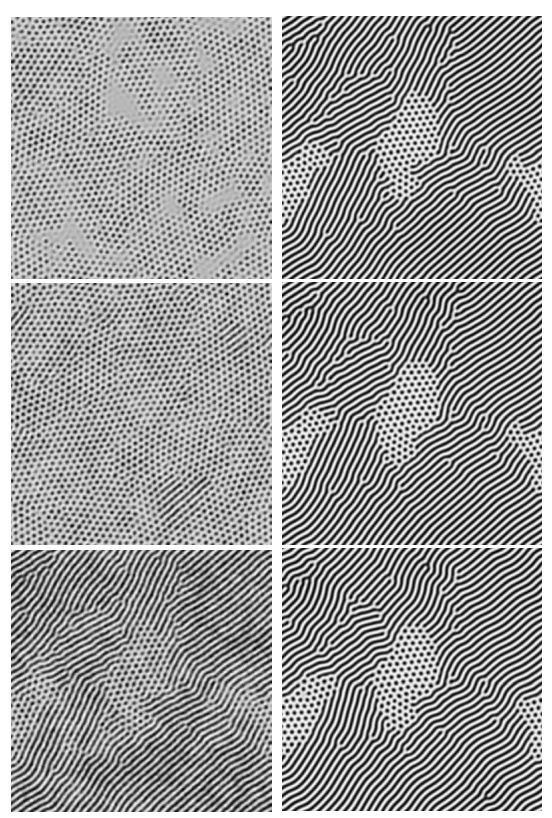

B

Рис. 3. Етапи еволюції системи при опроміненні та рекристалізації. Перші колонки на рисунку відповідають процесу опромінення: $a-$ при $D_{e}=0,35, \sigma^{2}=0,0 ; \sigma-$ при $D_{e}=0,475, \sigma^{2}=0,3 ;$ в - при $D_{e}=0,55, \sigma^{2}=0,3$. Другі колонки подають еволюцію системи при рекристалізації відповідних опромінених структур

стерігаються у стаціонарному режимі. Оскільки регулярна та стохастична компоненти потоку $\mathbf{J}_{e} \in$ конкуруючими у варіації ефективної температури (див. (11)), то, наприклад, при фіксованому значенні інтенсивності $\sigma^{2}$ та малому $D_{e}$ зовнішній шум буде протидіяти розтопленню областей кристала. У такому випадку атомна густина локально зменшується, однак геометрична структура залишається практично незмінною. За підвищених значень $D_{e}$ (див. колонку 1 на рис. $3, \sigma)$ у розтоплених областях в околі границь зерен дія шуму приводить до упорядкування з утворенням лінійних структур (страйпів), де атомна густина хоча і розподіляється періодично за атомними площинами, всередині площин є розмитою. Тобто, в утворюваних структурах атоми блукають вздовж атомних площин. Із подальшим збільшенням $D_{e}$ (див. колонку 1 на рис. 3,в) кристалічна система розтоплюється внаслідок дії регулярної частини потоку $\mathbf{J}_{e}$ та структурується за рахунок кореляційних ефектів стохастичного джерела з утворенням страйпів. Тобто такий характер опромінення сприятиме вибиванню атомів зі своїх положень та блуканням їх вздовж атомних площин. Якщо при фіксованому значенні $D_{e}$ збільшувати інтенсивність зовнішнього шуму, то виявляється, що система потрапляє в область існування стаціонарних структур лінійного типу. Ана- логічні ефекти співіснування кристалітів, занурених в область розтопленої конфігурації та конфігурації 3 розмитими атомними густинами вздовж атомних площин, спостерігалися при атомістичному моделюванні Монте-Карло [42-44].

Процес рекристалізації опроміненої системи у стохастичному випадку різниться від детерміністичного. Дійсно, тут крім кристалітів з меншою симетрією структури з більшою симетрією мають бути підлаштовані під дійсно кристалічні. Цей процес є доволі тривалим. Однак, після його завершення з кожної лінійної структури починається від'єднання одного атома, який у подальшому розширює область утвореного кристаліта. Картину такої рекристалізації наведено у колонках 2 на рис. 3,б,в. У випадку, коли більша частина системи знаходиться у гексагональній фазі (колонка 2 на рис. 3,б), спочатку відбувається перерозподіл атомної густини у кристалічній конфігурації - зменшення кількості дефектів для утворення ідеальної кристалічної структури, а потім від'єднання атомів з лінійних структур (локальне охолодження атомів, блукаючих вздовж площин). У випадку, зображеному у колонці 2 на рис. 3, в, лінійні структури 3 дефектами мають перерозподілитися у такий спосіб, щоб зайняти положення, сумісні з напрямками атомних площин. Після цього, залежно від співвідно- 


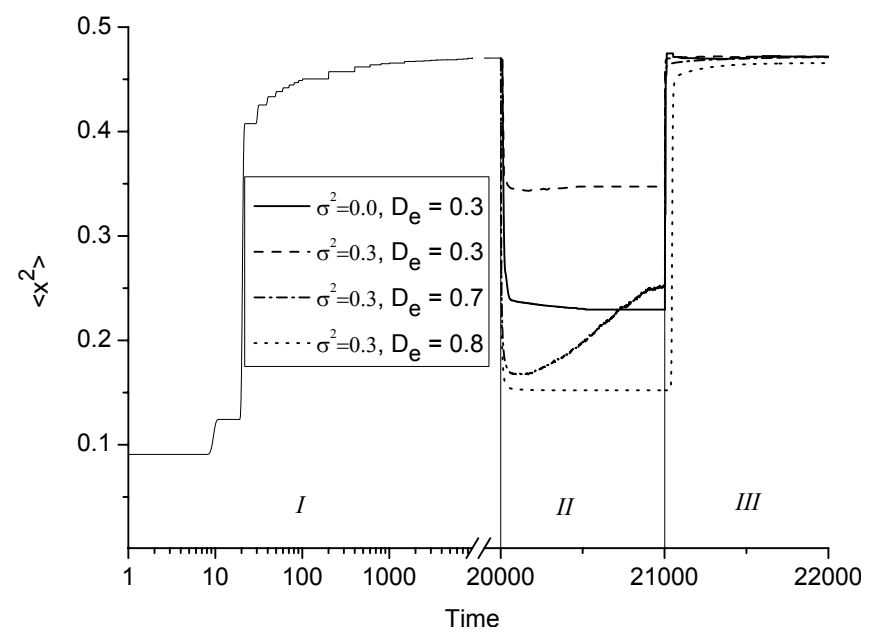

Рис. 4. Динаміка параметра порядку $\left\langle x^{2}\right\rangle$ при різних співвідношеннях $D_{e}$ та $\sigma^{2}$. Стадія $I-$ вирощування вихідного кристала, II - стадія опромінення, III - стадія рекристалізації

шення між частиною системи у гексагональній фазі та у фазі страйпів, може відбуватися формування кристалітів.

3 метою кількісного аналізу процесів упорядкування/розупорядкування прослідкуємо за поведінкою другого статистичного моменту $J(t)=N^{-2}\left\langle\sum_{\mathbf{r}} x_{\mathbf{r}}^{2}\right\rangle$, який у системах зі збережною динамікою є параметром порядку, в теорії структуроутворення він відомий як конвективний потік [19]. Загалом для систем зі збережною та незбережною динамікою відомо, що його зростання з часом свідчить про проходження процесів упорядкування. На рис. 4 наведено динаміку параметра порядку на різних стадіях: вирощуванню вихідного кристала відповідає стадія $I$; на стадії $I I$ відбувалося опромінення за різних умов; рекристалізація системи відбувалася на стадії III. Як видно, при $\sigma^{2}=0$ (суцільна крива) включення атермічного потоку приводить до зменшення параметра порядку, а при виключенні опромінення (стадія $I I I)$ релаксація системи проходить швидко до стаціонарного значення параметра порядку, яке спостерігалося при вирощуванні кристала. У стохастичному випадку (штрихова крива) при незмінному значенні $D_{e}$ параметр порядку спадає до стаціонарного значення, що перевищує реалізоване у детерміністичному випадку. Це свідчить про те, що зовнішні флуктуації внаслідок скорельованої дії сприяють підтримці упорядкованого стану. При збільшенні $D_{e}$ (штрих-пунктирна лінія) і незмінній інтенсивності $\sigma^{2}$ на початковій стадії опромінення відбувається розтоплення системи, тоді як шум сприяє встановленню порядку, підвищуючи зна- чення $\left\langle x^{2}\right\rangle$ на пізніх стадіях. За великих $D_{e}$ кореляційні властивості зовнішнього шуму хоча і підтримують порядок у системі, але вона стає неупорядкованою в сенсі перебудови кристала у структуру лінійних об'єктів. У процесі кристалізації відновлення кристалічної конфігурації опроміненої системи при великих $D_{e}$ протікає так, що параметр порядку не досягає свого стаціонарного значення, яке відповідало вирощеному кристалу. Отже, внесення додаткових збурень у вихідну конфігурацію може сприяти формуванню іншого типу просторових структур при рекристалізації. Останній ефект, очевидно, пов'язується із скорельованим перемішуванням системи, коли основну роль починають відігравати процеси індукованої шумом взаємодії атомної системи та перерозподіл і зміна кількості дефектів.

Як випливає із результатів моделювання, характер упорядкування опроміненої системи істотно залежить від умов опромінення. Відповідно до цього тип дефектів i ïx кількість при рекристалізації може змінитися. Слід зазначити, що величина $\left\langle x^{2}\right\rangle$, пропорційна площі під структурним фактором, $€$ інтегральною характеристикою і не може слугувати індикатором зміни мікроструктури кристала. Тому далі використаємо дослідження геометрії отриманих структур, обчислюючи кількість дефектів, їх еволюцію та характеристику неупорядкованих конфігурацій. У використаному у подальшому дослідженні формалізмі будемо відрізняти два типи дефектів: точкові (дефекти пакування) у кристалічній системі гексагональної симетрії та лінійні (дислокації) у системі лінійних структур.

При рекристалізації системи до гексагональної фази будемо визначати дефекти пакування за алгоритмом, розвинутим для дослідження двовимірних систем, що модельовані методами молекулярної динаміки [45]. У рамках такого підходу реальні атоми у молекулярній динаміці замінюються на "атоми" у методі фазового поля кристала. При цьому дослідження гексагональної симетрії відбувається аналогічно. Основні кроки цього методу є такими. Локальний кристалічний порядок можна описати орієнтацією шестикутників, точки яких відповідають максимумам атомної густини $x(\mathbf{r}, t)$. Тоді кут орієнтації $j$ го атома $\alpha_{j} \in[0, \pi / 3]$ визначається зі співвідношення $\Psi_{j}=\sum_{k \in n n(j)} \exp \left[6 i \theta_{j k}\right]=\left|\Psi_{j}\right| e^{6 i \alpha_{j}}$. Два атоми будуть межувати, якщо $\left|\mathbf{r}_{j}-\mathbf{r}_{k}\right|<1,25 \nu$, де $\nu$ - положення першого піка двочастинкової кореляційної функції; $\theta_{i}-$ кут між відповідним вектором $\mathbf{r}_{j}-\mathbf{r}_{k}$ та віссю $x$. Ступінь безладу $j$-го атома визначається за 


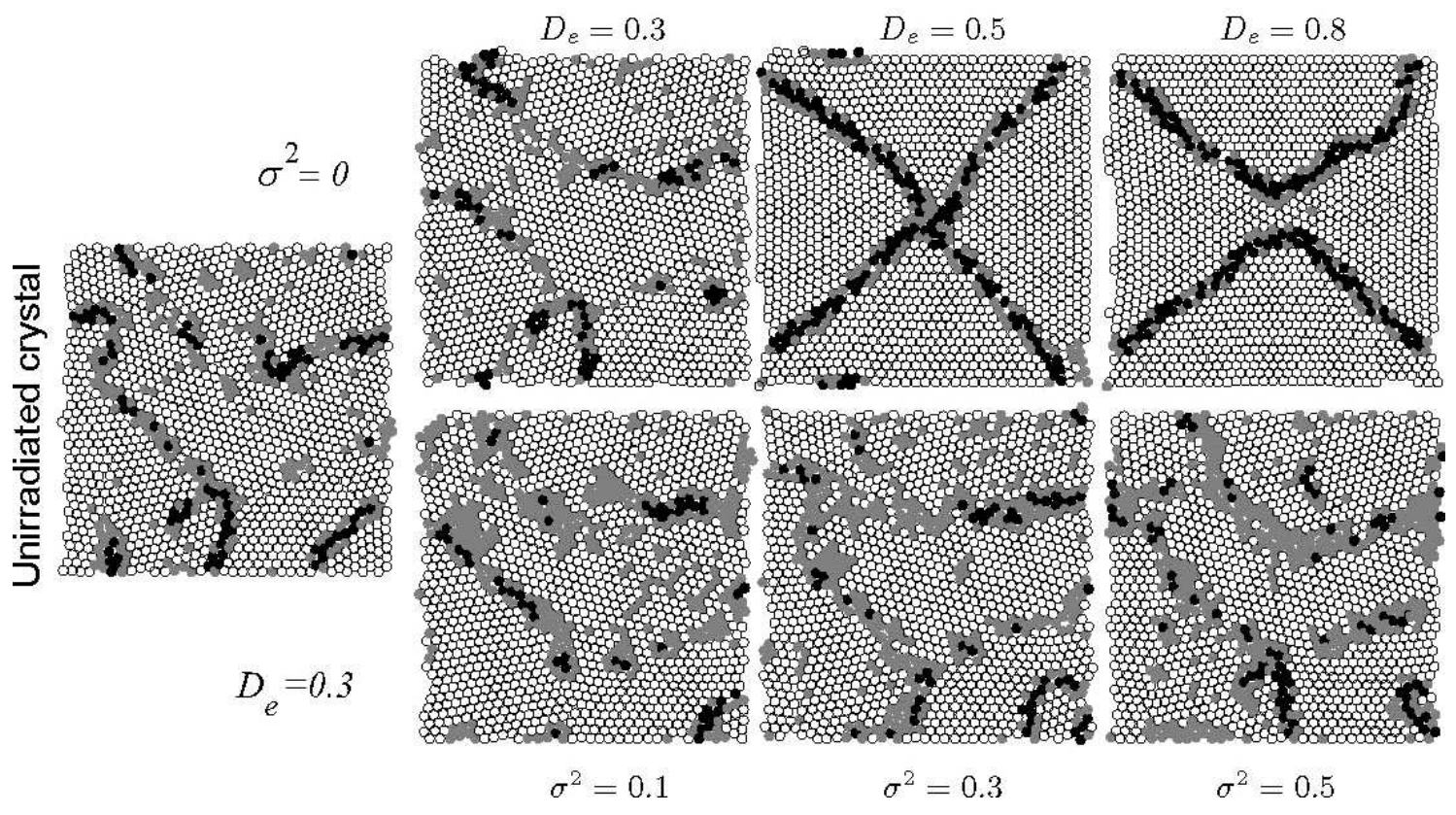

Рис. 5. Ілюстрація дефектності структур при рекристалізації опроміненої системи із початкової конфігурації, показаної зліва. Верхній рядок відповідає умовам опромінення при різних $D_{e}$ та фіксованій інтенсивності $\sigma^{2}$, нижній рядок відповідає умовам опромінення при різних $\sigma^{2}$ та фіксованому значенні $D_{e}$

формулою

$D_{j}=2 \sum_{k \in n n(j)}\left[1-\cos 6\left(\alpha_{i}-\alpha_{k}\right)\right]$.

Величину $D_{j}$, зазвичай, відображають у кольоровій гамі, це дозволяе явно оцінити ступінь дефектності геометрії кристала. У нашому випадку використано гаму сірого кольору: білі кружки характеризуються ідеальною геометрію гексагональної фази, чорні - найбільш дефектні структури (кількість найближчих сусідів $j$-го атома істотно відрізняється від 6). Останні утворюють границі зерен. Типову картину, що ілюструє локальний безлад після рекристалізації, наведено на рис. 5. Тут кружками зображено атоми (точки з максимальною атомною густиною), а їх колір показує значення локального параметра безладу кожного атома. Вихідний кристал зображено зліва. Наведені параметри зазначають умови, за яких відбулося опромінення. 3 верхнього рядка, що відповідає випадку $\sigma^{2}=0$ і різним значенням $D_{e}$, видно, що на стільки більше було розтоплення вихідного кристала на фінальній стадії рекристалізації, на скільки зерна стають крупнішими, що добре узгоджується із положеннями теорії рекристалізації. У стохастичному випадку опромінення при $D_{e}=0,3$ зростання шуму в певному інтервалі може приводити до сегрегації дефектів на границях зерен.

За поданою схемою обчислюємо кількість дефектів як атомів, що мають дефекти пакування (утворення з вакансіями, міжвузловинні атоми, ядра дислокацій). Динаміку відносної кількості дефектів $N_{\text {def }} / N_{\text {atoms }}$ при рекристалізації опроміненої системи з $\sigma^{2}=0$ наведено на рис. $6, a$, де $N_{\text {atoms }}-$ кількість атомів (піків атомної густини). Як видно, з часом кількість дефектів спадає до певного стаціонарного значення. Така картина є характерною при моделюванні методами молекулярної динаміки процесу рекристалізації після проходження каскадів [46,47]. Як видно з рис. $6, a$, при малих величинах $D_{e}$, коли зразок практично не змінився під слабкою дією опромінення, кількість дефектів залишається незмінною. Однак при збільшенні $D_{e}$ формується значна кількість дефектів (приблизно $75 \%$ від кількості атомів), їх кількість спочатку спадає за степеневим законом $t^{-\delta}$ з $\delta \simeq 0,2$, а потім, на дифузійних часах - логарифмічно повільно. Кількість дефектів, що залишилася після рекристалізації (у стаціонарному випадку) залежно від інтенсивності $D_{e}$ та дефектність геометрії типових структур, наведено на рис. 6,б. Як видно з рисунка, збільшуючи інтенсивність $D_{e}$ від нульового значення, характерного для неопроміненої системи, кількість де- 

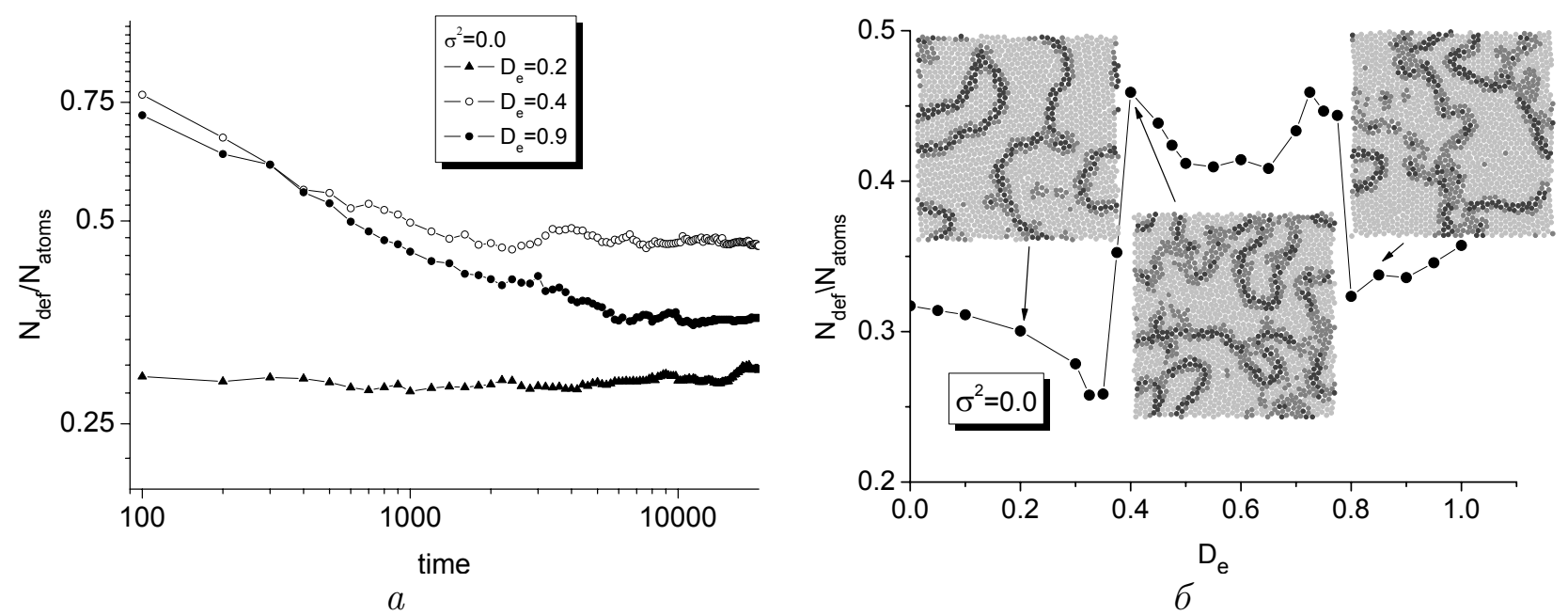

Рис. 6. Динаміка (a) та стаціонарні залежності (б) відносної кількості дефектів при $\sigma^{2}=0,0$ та різних значеннях інтенсивності балістичного перемішування

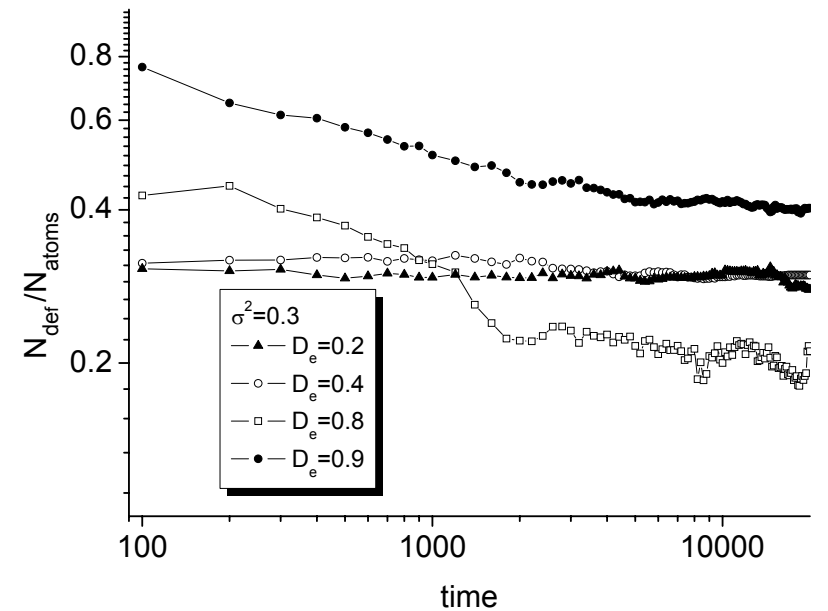

Рис. 7. Динаміка відносної кількості дефектів при $\sigma^{2}=0,3$, $\theta=0,7$ та різних значеннях інтенсивності балістичного перемішування

фектів поступово зменшується. Оскільки зростання $D_{e}$ приводить до підвищення ефективної температури, то така поведінка $N_{\text {def }}$ означає зменшення кількості дефектів (укрупнення зерен) при рекристалізації розігрітої системи, яка супроводжується перерозподілом атомів зі зменшенням енергії кристала. При характерних значеннях інтенсивності балістичного перемішування маємо два піки на залежності $N_{\mathrm{def}}\left(D_{e}\right)$. Вони фактично відповідають точкам "фазового" переходу для рівноважної системи, ефективна температура якої задається $\theta_{\mathrm{ef}}=\theta+D_{e}$. Критичні значення $D_{e}$ знаходяться на лініях рівноважної фазової діаграми $\theta_{\text {ef }}\left(x_{0}\right)$, які обмежують область існува- ння гексагональної фази. У такому сенсі стаціонарна залежність $N_{\text {def }}\left(D_{e}\right)$ відіграє роль ефективної геометричної сприйнятливості у процесах формування структур у системах, що описуються теорією фазового поля кристала.

У випадку опромінення зі стохастичним джерелом конкуренція регулярної та стохастичної компонент атермічного потоку приводить до того, що при малих $D_{e}$ та великих $D_{e}$ і малих $\sigma^{2}$ після рекристалізації система приходить до стану з гексагональною фазою. У такому випадку можна застосувати наведений формалізм визначення точкових дефектів. Відповідну часову залежність їх кількості подано на рис. 7 , де поведінка $N_{\text {def }} \in$ аналогічною до детерміністичного випадку. Однак, на відміну від нього, тут при аналогічних значеннях для $D_{e}$ (наприклад, $\left.D_{e}=0,4\right)$ не відбувається зменшення кількості дефектів. Це пов'язано із утриманням вихідної структури кристала шумом при опроміненні, тому кількість дефектів у такому випадку практично не змінюється.

У випадку, коли значення інтенсивності шуму збігаються з величиною $D_{e}$ або перевищують їі, мікроструктура системи змінюється. Замість гексагональної фази реалізуються страйпи (структури лінійного типу). Тоді застосування наведеного підходу визначення дефектів не може бути використано, оскільки атомна густина розмита вздовж атомних площин. Дефектами, які можуть бути досліджені у такому випадку є дислокації, дисклінації та границі зерен. У нашому випадку границь зерен не спостерігалося, дисклінацій було реалізовано менше $1 \%$ від повної кіль- 


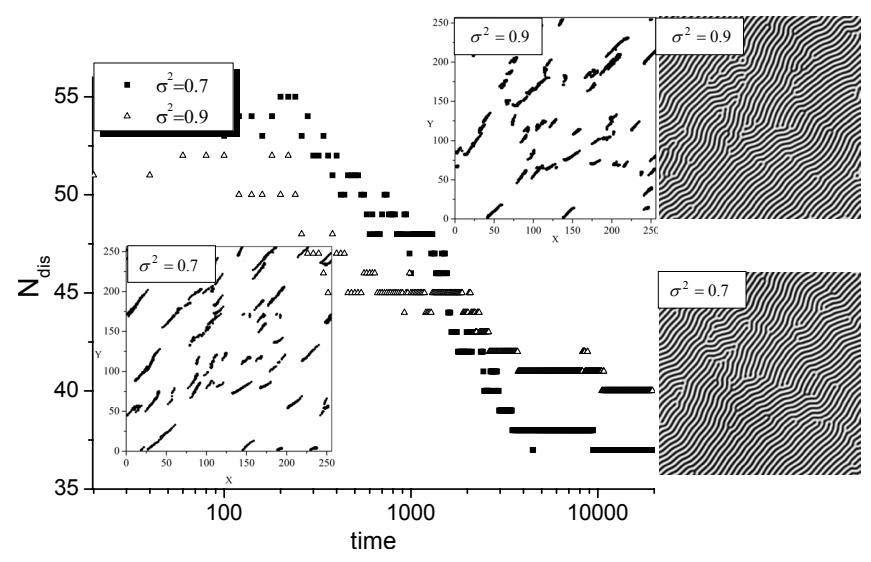

Рис. 8. Динаміка кількості дислокацій при $D_{e}=0,3$. На вставках - траєкторії руху дислокаційних ядер при $\sigma^{2}=0,7$ i $\sigma^{2}=0,9$ і типові стаціонарні лінійні структури. Решта параметрів: $\theta=0,7, r_{c}=1$

кості дефектів, тому у подальшому сконцентруємося на дослідженні лінійних дефектів як таких.

При дослідженні дислокацій використаємо підхід, розвинутий для дослідження дефектів у нематиках [48], де одним з мірників упорядкування є направляюче поле (директор) $\hat{n}(\mathbf{r})=\frac{\nabla x(\mathbf{r})}{|\nabla x(\mathbf{r})|}$ та відповідний нематичний параметр порядку $Q_{\alpha \beta}=Q_{0}\left[\hat{n}_{\alpha} \hat{n}_{\beta}-\frac{1}{2} \delta_{\alpha \beta}\right]$. Зокрема, для двовимірних систем роль параметра порядку відіграє величина $\cos (2 \theta)$, де $\hat{n}=$ $(\cos (\theta), \sin (\theta))$. Тобто існує певний векторний параметр порядку $\hat{\mathbf{B}}$, заданий виразами $\hat{B}_{x}=\hat{n}_{x}^{2}-\hat{n}_{y}^{2}$, $\hat{B}_{y}=2 \hat{n}_{x} \hat{n}_{y}$. Далі будемо вважати, що всі дефекти формуються $3 \pm \frac{1}{2}$ дисклінацій у направляючому полі $\hat{n}$, яке переходить у "вихори" заряду \pm 1 для поля $\hat{\mathbf{B}}$. Для ідентифікації дефектів визначимо ядра вихорів за формулою $A=\sum_{\alpha, \beta}\left(\nabla_{\alpha} B_{\beta}\right)^{2}$. В області дефекту значення $\hat{\mathbf{B}}$ зазнає різкої зміни. Таким чином, точка положення дефекту визначається за умови, що $A$ більше певного значення. Також можемо записати $A$ у вигляді

$A=\sum_{\alpha, \beta}\left(\nabla_{\alpha} n_{\beta}\right)^{2}=\left(\nabla_{\alpha} \varphi\right)^{2}$

де $\varphi(\mathbf{r}, t)=2 \theta(\mathbf{r}, t), \theta(\mathbf{r})=\arctan \left(\frac{\hat{n}_{y}(\mathbf{r})}{\hat{n}_{x}(\mathbf{r})}\right)$. Нематичний параметр порядку $Q_{\alpha \beta}$ повністю визначається кутом $\varphi(\mathbf{r})=2 \theta(\mathbf{r})$. Отже, знаючи похідну $\nabla \varphi(\mathbf{r})$, обчислення індикаторної величини $A(\mathbf{r})=|\nabla \varphi(\mathbf{r})|^{2}$ дозволяє визначити такі дефекти, як дислокації, дисклінації та границі зерен.

Метод заснований на тому, що в області дефекту (дислокації, дисклінації або границі зерна) поле $\varphi(\mathbf{r})$

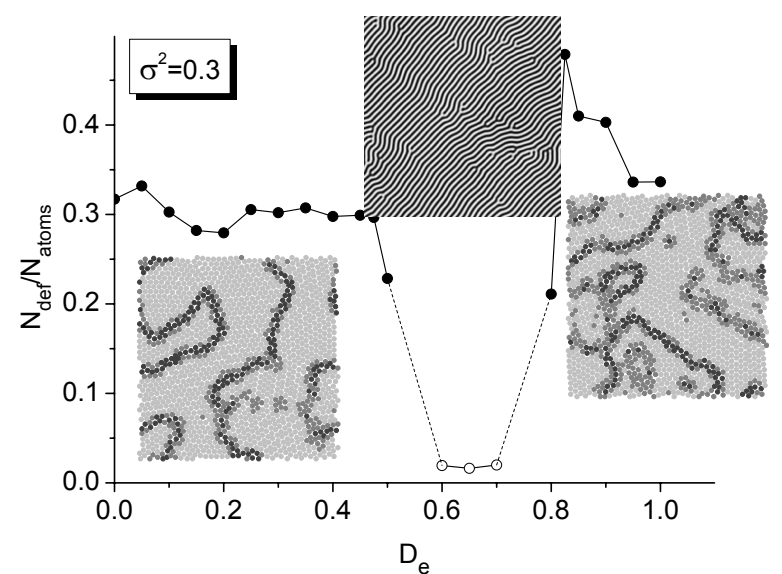

Рис. 9. Відносна кількість дефектів $N_{\text {def }} / N_{\text {atoms }}$ залежно від інтенсивності балістичного перемішування $D_{e}=0,3$ при $\sigma^{2}=$ 0,3 і типові стаціонарні структури (геометричну дефектність частинки (атома) проілюстровано у відтінках сірого кольору)

швидко змінюється, тоді як поза цими областями воно змінюється гладко. Отже, у точках з більшою інтенсивністю зміни $\varphi(\mathbf{r})$ знаходяться дефекти або частина границі зерна. Тоді в області поза дефектами $A(\mathbf{r}) \approx 0 . \mathrm{У}$ місці знаходження дефекту ця величина стрімко зростає. Описаний алгоритм допомагає визначити області, де поле директора суттєво змінюється. Таким чином, у будь-який момент часу є можливість визначити стан системи і наявність у ній зерен та дефектів.

Застосування поданого формалізму дозволило оцінити кількість дислокацій та їх рух. На рис. 8 зображено динаміку зміни кількості дислокацій $N_{\text {dis }}$, траєкторї руху ядер дислокацій у двовимірному просторі та характерні лінійні стаціонарні структури. Як видно з поведінки кількості дислокацій, спочатку рекристалізації їх кількість незначно збільшується внаслідок перебудови структури до найоптимальнішої із меншою пружною енергією. Згодом відбувається рекристалізація, і дислокації рухаються для перерозподілу накопиченої пружної енергії, анігілюючи з дислокаціями протилежного заряду. На великих часових інтервалах відбувається уповільнення руху дислокацій і їх кількість залишається незмінною. Таким чином, система із перебудованою структурою внаслідок дії опромінення може залишатися з меншою кількістю дефектів, але її структура може не збігатись зі структурою вихідного неопроміненого кристала.

Із наведеної процедури визначення дефектів можна отримати стаціонарну залежність кількості дефектів від коефіцієнта балістичної дифузії $D_{e}$ у стохастичному випадку. Відповідний результат подано 
на рис. 9. Як видно з рисунка, і за умови $\sigma^{2}=0$ (див. рис. $6, \sigma)$ у стохастичному випадку теж існують два критичних значення інтенсивності $D_{e}$. Однак на відміну від випадку детерміністичної системи тут неможливо виявити піки на залежності кількості дефектів, оскільки у піках є співіснування страйпів та гексагональної фази. Однак важливим є той факт, що у інтервалі критичних значень $D_{e}$ реалізується фаза лінійних об'єктів. Таким чином, вплив кореляційних властивостей зовнішнього шуму та їх конкуренція із регулярною компонентою балістичного потоку істотно впливає на зміну мікроструктури кристалічних систем, приводячи до структурного переходу, з формуванням стаціонарної структури, яка принципово відрізняється від структури вихідного кристала.

\section{4. Обговорення}

Із проведеного дослідження випливає, що внаслідок дії атермічного потоку структура вихідного кристала, що має гексагональну симетрію із дефектами пакування, може зазнавати змін. При цьому просторовий розподіл атомної густини може відповідати метастабільним структурам (змішаним структурам, або страйпам), які після виключення цього потоку релаксують у свої "рівноважні" конфігурації (гексагональну фазу). Для того щоб система перейшла із метастабільного стану до найбільш енергетично вигідного, що відповідає глобальному мінімуму функціонала вільної енергії $\mathcal{F}[x]$, необхідні флуктуації (термічного характеру) $\xi$, які б забезпечили такий перехід. Якщо інтенсивність цих флуктуацій буде достатньою, то перехід стає можливий за короткий часовий інтервал. Саме така картина спостерігається при слабкому зовнішньому шумові і малих та великих значеннях інтенсивності $D_{e}$. Однак, при низькій інтенсивності внутрішнього шуму $\xi$, час такого переходу може істотно зростати. Це пов'язано із глибиною локального мінімуму функціонала $\mathcal{F}[x]$ та характером взаємодії між атомами, який був нав'язаний зовнішнім впливом. При формуванні лінійних структур (страйпів), де атомна густина найближчих атомів перекривається, відповідні атоми стають сильно зв'язаними у порівнянні 3 атомами у гексагональній фазі. Тоді для переходу від конфігурації страйпів до вихідної гексагональної фази необхідно істотно розігріти систему, збільшуючи температуру $\theta$ (та інтенсивність внутрішніх флуктуацій $\sim \theta$ ). У нашому випадку спостерігалася еволюція системи лише після зняття атермічного потоку, тоді як температура $\theta$ не змінювалась. Таким чином, отримувані лінійні структури при слабкому внутрішньому шумові хоча і є стаціонарними, але відповідають метастабільній фазі (локальному мінімуму функціонала вільної енергії). Очевидно, якщо розігріти систему, підвищивши $\theta$, а потім знову охолодити до вихідного значення температури, то прийдемо до вихідної гексагональної структури кристала.

Важливим питанням при інтерпретації фази лінійних структур є їх фізичний зміст. Із проведеного дослідження випливає, що для них атомна густина розмивається вздовж атомних площин, розділених міжатомною відстанню $а$. Для з'ясування фізичної картини їх утворення слід звернутися до тривимірного випадку, де еквівалентом двовимірної гексагональної фази є ОЦК-структура. Тоді, оскільки відстань між найближчими сусідами становить $a \sqrt{3} / 2$, то найбільшому перекриттю атомних густин підлягатимуть атоми у напрямку [111], тоді як атоми в інших напрямках будуть розділені відстанню $a$, формуючи окремі атомні площини. Таким чином, двовимірні страйпи фактично будуть відповідати перекриттю атомних густин атомів у напрямку [111] для тривимірної системи. Фактично це пов'язується із кореляційним внеском шуму $D_{e} \sigma^{2} C(0) \nabla^{2} x$, який розширює радіус міжатомної взаємодії. Так, якщо перейти до ефективного потоку $\mathbf{J}_{\text {ef }}=-\nabla \delta \mathcal{F}_{\text {ef }}[x] / \delta x$, що враховує термічно стимульований потік та атермічний, то можна записати функціонал ефективної вільної енергії повної системи у вигляді

$$
\mathcal{F}_{\text {ef }}[x]=\int \mathrm{d} \mathbf{r}\left(\frac{1}{2} x \widehat{\epsilon}\left(\nabla^{2}\right) x+\frac{x^{4}}{4}+\frac{D_{e} \sigma^{2} C(0)}{2}(\nabla x)^{2}\right),
$$

де $\widehat{\epsilon}\left(\nabla^{2}\right) \equiv \varepsilon_{\text {ef }}+\mathcal{L}\left(\nabla^{2}\right), \varepsilon_{\text {ef }}$ має вигляд $(11)$, а $\mathcal{L}\left(\nabla^{2}\right)$ задає кристалічний порядок. За аналогією до теоії Кана-Хільярда ефективний радіус просторової взаємодії, викликаної дією зовнішнього джерела, буде характеризуватися складовою $\sim \sqrt{D_{e} \sigma^{2} C(0)}$. Отже, зовнішній шум сприятиме розширенню радіуса міжатомної взаємодії, сприяючи перекриттю атомних густин у напрямку [111]. У такому випадку гексагональні двовимірні структури є проекцією зрізу ОЦК кристала площиною (111) на площину (000), яка у нашому випадку є площиною $(x, y)$, тоді як страйпи відповідають проекції розмиття атомної густини в напрямку [111] на цю площину.

\section{5. Висновки}

У межах використання методу фазового поля кристала проведено моделювання процесів зміни мікроструктури кристалічних систем у процесі опромінен- 
ня, що характеризується внеском стохастичного потоку атермічного перемішування. Встановлено, що у ході опромінення відбувається розтоплення кристалічної структури на дефектах, що належать границям зерен. При цьому скорельована дія стохастичної компоненти балістичного потоку, конкуруючи із регулярною складовою потоку, сприяе підтриманню упорядкованої конфігурації кристала. При дослідженні процесів рекристалізації після зняття опромінення виявлено, що збуджена система переходить до стаціонарного стану із меншою кількістю точкових та лінійних дефектів. У стаціонарному режимі виявлено, що шум зовнішнього потоку може приводити до формування просторових структур розподілу атомної густини, коли вона розмивається вздовж атомних площин у напрямку щільного пакування. Такі структури, будучи метастабільними, є стаціонарними за рахунок встановленої сильної взаємодії атомів з перекритими густинами. Перехід до рівноважної вихідної кристалічної конфігурації стає можливим лише при підвищенні температури системи.

1. A. Onuki, Phase Transition Dynamics (Cambridge University Press, Cambridge, 2004).

2. В.Н. Воеводин, И.М.Неклюдов, Эволюиия структурно-фазового состояния и радиационная стойкость конструкционных материалов (Наукова думка, Київ, 2006).

3. B.D. Wirth, M.J. Caturla, T. Diaz de la Rubia, T. Khraishi, and H. Zbib, Nucl. Instrum. Methods B 180, 23 (2001).

4. А.Г. Хачатурян, Теория фазовых превращений и структура твердых растворов (Наука, Москва, 1974).

5. J. Swift and P.C. Hohenberg, Phys. Rev. A 15, 319 (1977).

6. T.V. Ramakrishnan and M. Yussouff, Phys. Rev. E 19, 2775 (1979).

7. K.R. Elder, M. Katakowski, M. Haataja, and M. Grant, Phys. Rev. Lett. 88, 245701 (2002).

8. P.F. Tupper and M. Grant, Europhys. Lett. 81, 40007 (2008).

9. K.R. Elder and M. Grant, Phys. Rev. E 70, 051605 (2004).

10. J. Berry, M. Garnt, and K.R. Elder, Phys. Rev. E 73, 031609 (2006).

11. Y.M. Jin and A.G. Khachaturyan, J. Appl. Phys. 100, 013519 (2006).

12. K.R. Elder, N. Provatas, J. Berry, P. Stefanovich, and M. Grant, Phys. Rev. B 75, 064107 (2007).

13. J. Berry, K.R. Elder, and M. Grant, Phys. Rev. E 77, 061506 (2008).
14. A. Jaatinen, C.V. Achim, K.R. Elder, and T. Ala-Nissila, Phys. Rev. E 80, 031602 (2009).

15. G. Martin, Phys. Rev. B 30, 1424 (1984).

16. S. Matsumara, Y. Tanaka, S. Müller, and C. Abromeit, J. Nucl. Mater. 239, 42 (1996).

17. R. Enrique and P. Bellon, Phys. Rev. Lett. 84, 2885 (2000).

18. V.I. Dubinko, A.V. Tur, and V.V. Yanovsky, Radiat. Eff. Defects Solids 112, 233 (1990).

19. J. Garcia-Ojalvo and J.M. Sancho, Noise in Spatially Extended Systems (Springer, New York, 1999).

20. А.И. Олемской, Д.О. Харченко, Самоорганизация самоподобных стохастических систем (Регуляная и хаотическая динамика, Москва-Ижевск, 2007).

21. Д.О. Харченко, В.О. Харченко, А.В. Дворниченко, Прочессы упорядочения сложных систем (Наукова думка, Київ, 2011).

22. A.I. Olemskoi, D.O. Kharchenko, and I.A. Knyaz', Phys. Rev. E 71, 041101 (2005).

23. D.O. Kharchenko and A.V. Dvornichenko, Physica A 387, 5342 (2008).

24. D.O. Kharchenko, S.V. Kokhan, and A.V. Dvornichenko, Physica D 238, 2251 (2008).

25. D.O. Kharchenko, V.O. Kharchenko, I.O. Lysenko, and S.V. Kokhan, Phys. Rev. E 82, 061108 (2010).

26. D.O. Kharchenko, V.O. Kharchenko, and I.O. Lysenko, Phys. Scr. 83, 045802 (2011).

27. R.S. Averback, T. Diaz de la Rubia, and R. Benedek, Nucl. Instrum. Methods B 33, 693 (1988).

28. T. Diaz de la Rubia, R.S. Averback, and H. Hsieh, J. Mater.Res. 4, 579 (1989).

29. M.-J. Caturla, T. Diaz de la Rubia, L.A. Marques, and G.H. Gilmer, Phys. Rev. B 54, 6683 (1996).

30. H. Ohnogi and Y. Shiwa, Physica D 237, 3046 (2008).

31. A. Jaatine and T. Ala-Nissila, J. Phys. Condens.Matter 22, 205402 (2010).

32. G.I. Toth, G. Tegze, T. Pusztai, G. Toth, and L. Granasy, J. Phys. Condens. Matter 22, 364101 (2010).

33. D. Kharchenko, I. Lysenko, and V. Kharchenko, Physica A 389, 3356 (2010).

34. D.O. Kharchenko, V.O. Kharchenko, and I.O. Lysenko, Cent. Eur. J. Phys. 9, 698 (2011).

35. Е.А. Новиков, ЖЕТФ 20, 1290 (1965).

36. Д.О. Харчено, І.О. Лисенко, В.О. Харченко, Металлофиз. новейшие технол. 32, №6, 783 (2010).

37. Д.О. Харчено, І.О. Лисенко, В.О. Харченко, УФЖ 55 , No. 11, 1226 (2010).

38. D.O. Kharchenko, I.O. Lysenko, and S.V. Kokhan, Eur. Phys. J. B 76, 37 (2010). 
39. J. Garcia-Ojalvo, A.M. Lacasta, J.M. Sancho, and R. Toral, Europhys. Lett. 42, 125 (1998).

40. M. Ibanes, J. Garcia-Ojalvo, R. Toral, and J.M. Sancho, Phys. Rev. E 60, 3597 (1999).

41. Д.О. Харченко, А.В. Дворниченко, І.О. Лисенко, УФЖК 53, №9, 917 (2008).

42. R.A. Enrique and P. Bellon, Phys. Rev. E 63, 134111 (2001).

43. J. Ye and P. Bellon, Phys. Rev. B 70, 094104 (2004).

44. J.Ye and P. Bellon, Phys. Rev. B 70, 094105 (2004).

45. T. Yamanaka and A. Onuki, Phys. Rev. E 77, 042501 (2008).

46. K. Nordlund, M. Ghaly, R.S. Averback, M. Caturla, T. Diaz de la Rubia, and J. Tarus, Phys. Rev. B 57, 7556 (1998).

47. D.J. Bacon, Yu.N. Osetsky, R.E. Stoller, and R.E. Voskoboinikov, J. Nucl. Mater. 323, 152 (2003).

48. H. Qian and G.F. Mazenko, Phys. Rev. E 73, 036117 (2006).

Одержано 30.11.11

\section{МОДЕЛИРОВАНИЕ ИЗМЕНЕНИЯ МИКРОСТРУКТУРЫ ОБЛУЧАЕМЫХ СИСТЕМ МЕТОДОМ ФАЗОВОГО ПОЛЯ КРИСТАЛЛА}

Д.О. Харченко, В.О. Харченко, С.В. Кохан, И.О. Лъсенко

$\mathrm{P}$ е $з$ ю м е

Проведено исследование микроструктуры систем под воздействием баллистического потока, который описывает формирование структурного беспорядка при облучении с применением метода фазового поля кристалла. Обнаружено, что конкурен- ция регулярной и стохастической компонент баллистического потока может приводить к формированию в системе структур с размытыми атомными плотностями. Проведено исследование динамики дефектов при рекристаллизации такой системы и установлен характер изменения количества дефектов в зависимости от статистических свойств баллистического потока. Установлено, что пространственные структуры, сформированные под воздействием такого потока, являются стационарными и устойчивыми к термическим флуктуациям малой интенсивности при рекристаллизации.

\section{MODELING OF MICROSTRUCTURAL CHANGES IN IRRADIATED SYSTEMS USING THE PHASE FIELD CRYSTAL METHOD}

D.O. Kharchenko, V.O. Kharchenko, S.V. Kokhan, I.O. Lysenko

Institute of Applied Physics, Nat. Acad. of Sci. of Ukraine (58, Petropavlivska Str., Sumy 40030, Ukraine; email: dikh@ipfcentr.sumy.ua)

$\mathrm{S} \mathrm{u} \mathrm{m} \mathrm{m} \mathrm{a} \mathrm{r} \mathrm{y}$

Microstructural changes in systems subjected to the ballistic flux action have been studied. The formation of a structure disorder under irradiation has been described using the phase field crystal method. It is found that, owing to a competition between the regular and stochastic components of the ballistic flux, spatial patterns with smeared atomic densities can be formed. The dynamics of defects during the recrystallization in such systems has been studied, and the dependence of the variation in the number of defects on the statistical properties of a ballistic flux has been analyzed. The spatial patterns formed under the action of such flux during the recrystallization are found to be stationary and resistant to low-intensity thermal fluctuations. 